\title{
Göçmen Kadınlar ve Devletsiz Neslin Çocukları: Hak Mahrumiyetinden Yoksulluğ ${ }^{1}$
}

\section{Refugee Women and Children of a Stateless Generation: From Rightlessness to Poverty}

Araş. Gör. Özlem Ünlü²

Öz

$\mathrm{D}$ ünyada hâlihazırda devam eden mülteci krizi, büyük ancak gizli devletsizlik sorunlarından birini açığa çıkardı. Suriye iç hukukuna göre çocuklara vatandaşlık devri, sadece erkeklere verilmiştir. Birleşmiş Milletler Antlaşması her ne kadar üye devletlere, kendi topraklarında doğan çocuklara uyruk vermeyi zorunlu kılsa da, Suriyeli göçmen kadınların, muhtemelen iç savaşta ölmüş olan bir baba olmaksızın, çocuklarını Suriye uyruklarıyla kayıt yaptıramamalarından dolayı pek az ülke bu ilkeyi doğru bir şekilde uygulamaya sokma eğilimindedir. Böylelikle Suriyeli çocuklar, dünyanın her tarafına yayılmış yaklaşan bir nesil olarak uzun vadede devletsiz bırakılmıştır; bu çocuklar yalnızca kendi uyruklarından yoksun değil, aynı zamanda doğdukları ülkelerin uyruklarından da yoksundur. Göçmen kadınlar çocuklarının yasal olarak işe giremeyeceklerinin, mülk sahibi olamayacaklarının ve hatta okula bile gidemeyeceklerinin farkında değiller. Diğer bir deyişle, göçmen kadınlar, sırf kadın olduklarından dolayı içinde bulundukları bu hak mahrumiyetinin, çocuklarını nasıl da alabildiğine yoksulluğa sürükleyeceğinin farkında değiller.

Bu makalede toplumsal bir sorun olan yoksulluğun keskin bir şekilde siyasetle ilişkili olduğunu, özellikle bu örnekte hak siyasetiyle ilişkili olduğunu felsefeci bir yaklaşımla öne süreceğim. Bunu yapmak için çağın en önemli siyaset kuramcılarından biri olan Hannah Arendt'in insan haklarının paradoksal doğasını ortaya çıkardığı çözümlemesine ve bütünüyle devletsizlikle sonuçlanan çıplak insan varlığı anlayışını birbirine eklemleyeceğim. Daha sonra, yine Arendt'in "toplumsal olan” ve "siyasal olan” arasında yaptığı keskin ayrımına başvuracağım. Arendt’e göre modern zihniyet için, siyasal olan, toplumsal olanın sorunlarıyla (yoksulluk) işgal edilmiştir. Arendt'in bu ayrımı,

\footnotetext{
13 Mart 2016 tarihinde KADEM tarafından düzenlenen "II. Toplumsal Cinsiyet Adaleti Kongresi: Kadın ve Yoksulluk" başlıklı kongrede bildiri olarak sunulmuştur.

2 Araştırma Görevlisi, Orta Doğu Teknik Üniversitesi Felsefe Anabilim Dalı, ozlmunlu@gmail.com 
katı da olsa değerini korumaktadır. Buradan yola çıkarak, yoksulluk gibi toplumsal sorunların, ortak bir kaygı meselesi olarak kamusallaştırma pratiklerine gerek duyduğunu, aksi takdirde özel alanda kalarak unutulacağını öne süreceğim. Bu pratikler, titizlikle yapılması gereken temsil pratikleridir. Son olarak, Suriyeli mülteci kadın figürünü, Türkiye ve yakın zamanda sunulan olası yurt edinme hakkı bağlamında konumlandırmaya çalışacağım.

Anahtar Kelimeler: Arendt, Suriyeli göçmenler, Kadın, Yoksulluk, Hak mahrumiyeti, Devletsizlik

\section{Abstract}

$\mathrm{T}$ he world's ongoing refugee crises unveils one of the huge but hidden problem of statelessness that under Syrian domestic law the right to pass citizenship on to children is granted to only men. Although The UN convention obliges the member governments to confer nationality to any child who is born in their territory, only a few countries have intended to implement the principle properly, partly due to the fact than Syrian refugee women cannot even register their children as Syrian nationals without a Syrian father who had most probably died during the civil war. Thus Syrian children as a coming generation scattered all over the world have long been left stateless. They are not only deprived of their own nationality, but also of the nationality of any country in which they are born. Refugee mothers are generally unaware that their children with no legal citizenship will be unable to be legally employed, to own property or even go to school. In other words, refugee mothers are unaware how their rightlessness, by virtue of being woman, will lead their children to marginalization and thus utmost poverty.

In this paper, I will propose a philosophical approach to how the social problem of poverty is acutely related to the political one, especially to the politics of right in this case. In order to do this, I first evoke one of the most important contemporary political theorists Hannah Arendt's analysis of paradoxical nature of human rights and the resulting conception of naked human being, which utterly leads to statelessness. After this, I articulate Arendt's rigorous distinction between 'the social' and 'the political', where the former's problems (i.e., poverty) occupy the latter in modern mentality. Having accepted that Arendt's distinction is indeed more than strict, but still invaluable, I then propose that the social problems such as poverty demand publicizing practices as a matter of common concern which would otherwise be destined to be forgotten as a private issue, with a particular emphasis on the representative practices which is supposed to be performed meticulously. Lastly, I locate the critical figure of the Syrian refugee mother in the context of Turkey and the newly proposed category of possible rights of having a homeland. 
Key Words: Arendt, Syrian refugees, woman, poverty, rightlessness, statelessness

\section{Giriş}

Curiye'de 2011 yılı Mart ayından bu yana, dramatik bir biçimde yayılarak ve ağırlaşarak devam eden kriz, 470 bin insanın ölümü ve 11 milyondan fazla insanın yerinden edilmesiyle devam ediyor. ${ }^{3}$ Küresel çapta süregelen mülteci krizi, büyük ama gizli devletsizlik sorunlarından birini daha açığa çıkardı: Sanaa, Berlin'de Siba adlı bir kız çocuğu dünyaya getirdikten sonra kızına pasaport almak üzere Suriye Büyükelçiliği’ne gittiğinde kendisine, "çocuğun babasının Suriyeli olması ve anne-babanın evli olması gerektiği” bildirilerek çocuğun pasaport talebinin reddedildiğini aktarıyor (Osborne ve Russell, 2015). Bu örnekte görüldüğü gibi, açık bir biçimde cinsiyet temelli ayrımcılığa dayalı Suriye medeni hukuku gereği, Suriyeli çocuklara yurttaşlık devri, sadece erkeklere verildiğinden Suriyeli anneler çocuklarının yasal babaları olmaksızın onları Suriye vatandaşı yapamıyor.

Siba’nın yurttaşlık hakkı aslında, tam da Almanya'da doğduğu için Birleşmiş Milletler 1989 Çocuk Hakları Sözleşmesi ile güvence altında olması gerektiği halde Almanya kendi iç hukukuna dayanarak Siba’ya yurttaşılı hakkı tanımıyor. Birleşmiş Milletler her ne kadar üye devletlere Çocuk Hakları Sözleşmesi’ne ${ }^{4}$ dayanarak kendi topraklarında doğan çocukların, doğumlarından itibaren nüfus kaydı zorunluğu getirse de, BM üyesi bu ülkeler bu sözleşmeyi uygulamaktan kaçınarak kendi iç hukuk ilkelerine göre düzenlemeler getirmekteler.

Kıta Avrupası hukuk sisteminde yurttaşlık hakkı iki ilkeye göre belirlenir; jus sanguinis ilkesine göre her ülke, kendi yurttaşlarının çocuklarına yurttaşlık hakkı tanırken; jus soli ilkesine göre ise, ülkeler kendi topraklarında doğan tüm çocuklara yurttaşlık hakkı verir. Batı iç hukukunda bir takım farklılıklar mevcut. Britanya ve Amerika jus soli ilkesinden hareketle kendi topraklarında doğan tüm çocuklara yurttaşlık hakkı tanır. Ancak koşulsuz görünen bu ilke belli düzenlemelerle uygulamaya sokulmuş,

3 Bu veriler Suriye Siyasi Araştırma Merkezi'nin (Syrian Center for Policy Research - SCPR) 11 Şubat 2016 tarihli "Confronting Fragmentation" başlıklı raporuna dayanmaktadır; http://scpr-syria.org/publications/policy-reports/confronting-fragmentation/

Bu makalede başvurulan eserlerden ve hukuki metinlerden yapılan alıntıların bazılarını Türkçe çevirisi olmadığı için, bazılarını ise çevirisi olmasına rağmen yaptığım ufak tefek düzeltmelerle daha iyi ifade ettiğimi düşündüğüm için ben çevirdim. Dolayısıyla metnin içinde yer alan alıntıların çevirileri, aksi belirtilmediği sürece tarafımdan İngilizce metinler esas alınarak yapılmıştır.

4 BM Çocuk Hakları Sözleşmesi (1989), Madde 7:

i-Çocuk doğumdan hemen sonra derhal nüfus kaydı yapılacak ve doğumdan itibaren isim hakkına, bir uyruğa (nationality) sahip olma hakkına ve olabildiğince ebeveynlerini tanıma ve ebeveynlerinin kendisine bakma hakkına sahip olacaktır.

ii-Taraf Devletler, özellikle çocuğun aksi takdirde devletsiz kalacağı durumlarda, kendi ulusal hukuklarına ve bu alandaki ilgili uluslararası dokümanlarla tanımlanmış yükümlülüklerine uygun olarak bu hakların uygulanmasinı taahhüt ederler (UNHR, 1989). 
örneğin Britanya kendi yurttaşı olmayan ebeveynlerin çocukları için, en azından bir ebeveynin Britanya sınırları içinde kayıtlı halde yerleşik olması şartını getirmiştir (Brubaker, 1994, s. 81, 206).

İkisi de jus sanguinis ülkesi olan Fransa ve Almanya’ya baktığımızda ise oldukça farklı iki durum görürüz ${ }^{5}$; Fransa’nın jus soli ilkesine dayanarak getirdiği düzenlemeler mevcut ama Almanya yurttaşlığı bu ilkeyi tamamen dışlıyor. Fransa, yurttaşlık için ebeveynlerden en az birinin Fransa'da ya da eski Fransız kolonilerinde doğmuş olma şartını getiriyor. Fransa yurttaşı olmayan ailelerin çocukları ise, en az beş yıl ikamet ve kriminal kaydı olmamak şartıyla 18 yaşında yurttaşlık edinebiliyor. Almanya yurttaşlık hukuku ise, ülke topraklarında doğmuş olmak gibi bir ilkeyi veya uzun süre ikamet etmek gibi koşulları reddederek yalnızca "yurttaşlığa kabul” (naturalization) prosedürüyle yurttaşlık hakkı veriyor. Türkiye Cumhuriyeti vatandaşlarının dahil olduğu üçüncü nesil göçmenler dahi doğallaştırma dedikleri yasal bir süreçle yurttaşlık edinebiliyor (Brubaker, 1994, s. 81-82). Türkiye'nin yurttaşlık hukuku ise tıpkı Fransa gibi, Kıta Avrupası hukuk diliyle ifade edersek, bütünüyle jus soli ilkesine dayanır. ${ }^{6}$

Berlin'de doğan ve Suriyeli bir babası olmadığı için Suriye yurttaşlı̆̆ı alamayan, yine tam da bu nedenle Almanya'nın doğallaştırma yasal sürecine başvuru bile yapamayan Siba’nın durumu ne olacak? Suriye iç hukukunun ayrımcı düzenlemeleri nedeniyle, Siba’ya nüfus cüzdanı alamayan annesi Sanaa’nın sırf kadın olduğu için bu durumda kaldığı açık. Peki Almanya Federal Cumhuriyeti, en azından böyle bir hakkaniyetsizliğin önüne geçmek için BM İnsan Hakları Yüksek Komiserliği’nin denetiminde olan Çocuk Hakları Sözleşmesi Madde 7’yi uygulamaya sokamaz mı? Siba bu koşullarda yaşamının sonuna dek yurttaşlık hakkı elinden alınmış ve devletsizliğe mahkum edilmiş görünmektedir; yalnızca doğduğu ülkenin yurttaşlığını değil, anne babasının geldiği ülkenin yurttaşlığını da alamayacak olan Siba kelimenin tam anlamıyla mutlak bir biçimde devletsiz kalmıştır.

Suriyeli mülteci kadınların pek çoğunun eşlerini, hamile oldukları sırada Suriye iç savaşında kaybettiği göz önüne alındığında, Lübnan'da doğan 30 bin ve Türkiye'de doğan 60 bin Suriyeli çocuğun Siba ile aynı durumda olması bizi şaşırtmıyor. ${ }^{7}$ Bunun yanı sıra, özellikle Lübnan'da cinsel saldırı sonucu istenmeyen gebeliklerin görülme

5 Devam eden Suriye mülteci krizinde en çok sığınma talebi alan Fransa ve Almanyảnın üzerinde biraz daha durdum. Diğer Avrupa ülkelerinin kendi düzenlemeleri mevcut. Belçika ve Hollanda üçüncü nesil göçmenlere uyruk (nationality) veriyor. Avusturya, Belçika, Hollanda, Finlandiya ve Norveç, topraklarında doğanların ikamesine bir süre izin veriyor ancak bu ülkelerde yurttaşlık muğlak bir ifadeyle "olgunluk çağında" veriliyor. İtalya ikame süresini on yıl olarak belirlemiş. İsveç için ise, doğum değil, olgunluk çağına kadar ikame yeterli oluyor (Brubaker, 1994, s. 206).

6 T.C. İç İşleri Bakanlığı Nüfus ve Vatandaşlık İşleri Genel Müdürlüğü’nün, “Türk Vatandaşlığı Kanununun Uygulanmasına İlişkin Yönetmelik, Vatandaşlı̆ıı Kazanılması, Kanun Yolu İle Kazanma” yönetmeliğinde, dogum yerini esas alan madde; Madde 7- Türkiye’de doğan ve ana babalarının belli olmaması veya vatansız bulunmaları gibi sebeplerle veyahut milli kanunları gereğince onların vatandaşlığını doğumla kazanamayan çocuklar, doğumlarından başlayarak Türk vatandaşıdırlar. Türkiye’de bulunmuş çocuklar Türkiye dışında doğduğu sabit olmadıkça Türk topraklarında doğmuş sayılırlar (İç İşleri Bakanlığı, 1964)

7 Osborne ve Russell'ın haberine göre bu konuda henüz bir çalışma yapılmadığı için rakamlar tahmini (Osborne ve Russell, 2015). 
oranı oldukça yüksek. Eşlerini kaybeden kadınların, ev sahibi ülkedeki erkekler tarafından "sahipsiz" görülmesi, cinsel saldırıların en büyük gerekçesi haline geldiği belirtiliyor. Bu türden cinsel saldırılar sonucu doğan çocuklar da yurttaşlık hakkından mahrum olmakla birlikte, bu şekilde dünyaya gelmiş babasız çocukların geçimini tek başına yüklenen annelerin yüzde 70’i Lübnan için belirlenen yoksulluk sınırının altında yaşıyor (Collins, 2016). Süregelen ulusal ve uluslararası hukuki sistemin en büyük mağdurunun mülteci anneler olduğunu söylemek yanlış olmaz çünkü mülteci kadınların yoksulluk sorunu, ne nedenleri ne de sonuçları bakımından sade bir yurttaşın yoksulluk sorunuyla eş düzlemde ele alınabilir görünmektedir.

Mülteci annelerin ne kadar yoksul oldukları, ev sahibi ülkelerin refah devleti olup olmamasına göre değișebilir. Ancak Siba’nın durumu bize değişmeyen bir şeyi gösteriyor; Lübnan'da, Almanya’da ya da Türkiye’de olması fark etmez, Suriyeli kayıt dışı çocuklar, dünyanın her tarafına yayılmış yaklaşan bir nesil olarak uzun vadede devletsizliğe mahkum edilmiştir. Bunun nedeni Almanya örneğindeki gibi mülteci kabul sürecinin farklılığından kaynaklı olabilir ya da jus soli ülkesi olan Türkiye gibi ülkelerde ulusal hukukun uygulanmamasından kaynaklı da olabilir. Suriye mülteci krizinin bu yıkıcı sorunu, tek tek ülkelerin hukukunda değil, kitlesel göç hareketleri arttıkça kendini daha iyi gösteren ulus-devlet egemenlik anlayışında yatmaktadır.

Siba örneği, yayılmış devletsizlik sorununun, tek tek devletlerin yasal uygulama sorunu olmadığını görmek için önemli bir örnektir. Tek tek ülkeler, BM İnsan Hakları Yüksek Komiserliği’nin denetiminde olan Çocuk Hakları Sözleşmesi’ni elbette devreye sokabilirler. Zaten Birleşmiş Milletler gibi uluslararası kuruluşlar tam da bu türden amaçlarla kurulmamış mıdır? Önceleri Milletler Cemiyeti olan Birleşmiş Milletler, pek çok uluslararası alt organizasyon aracılığıyla tek tek ülkelerin ulusal yasalarının keyfiyetle ihlal edebileceği hakları, üst insan hakları normlarını iç hukuka tanıştıran bir bürokrasi geliştirme yoluyla koruma altına almıştır. Uluslararası kuruluşlar, kitlesel göç hareketlerinin yarattığı mülteci sorunuyla bu bürokrasi aracılı̆̆ıyla yüzleşmeye çalıştılar ve halen de çalışıyorlar. Ancak bu bürokrasi bugün işlemez haldedir. Bunun nedenini, bu kurumların kendilerini tanımlayış biçiminde görebiliriz. Uluslararası kuruluşların mültecilerle ilgili alt organizasyonların en büyügü Birleşmiş Milletler’e bağlı Mülteciler Yüksek Komiserliği (BMMYK), kendisini siyasi değil, toplumsal ve insani yardım kuruluşu olarak tanıtır. ${ }^{8}$ Bunun sakıncalarını anlamak için Arendt'in siyaset kuramındaki devletsizler açıklamasına bakmak gerekecek.

\section{Soyut İnsan Tasarımı ve Devletsizlik}

Etnik azınlık yurttaşlı̆̆ının, egemen siyasi otoritenin bünyesinde barındıramadığı bir kategori olmasıyla, kendi vatandaşlarını ulus dışına atan (denationalization) modern ulus-devlet deneyimi, yurttaşlık kavramında bir dönüm noktasıdır (Agamben, 2000, s. 16-17). Hobsbawm’n ifade ettiği gibi, "Dünya astronomik ölçekte zorla sürgün ve öldürmelere öyle alıştı ki bu yabancı fenomenleri anlatmak için yeni sözcükler icat

8 http://www.unhcr.org/pages/49c3646c107.html 
etmek gerekti” (Hobsbawm, 1994, s. 66). İki dünya savaşı arasında icat edilen bu yeni kategori "devletsiz" kavramıla karşılandı. Birinci Dünya Savaşı’nın sonunda imzalanan barış antlaşmalarının yeni düzenlemeleriyle birlikte gelen demografik felaket sonucu pek çok etnik ve dini azınlık ülkelerini terk etmek zorunda kalmıştır.

Bundan yaklaşık yetmiş yıl önce siyaset kuramcısı Hannah Arendt, devletsiz insanların ortaya çıkışını, teritoryal egemenliğe dayalı ulus-devletlerin de facto çöküşünün semptomu olduğunu iddia ediyordu. Arendt’in çözümlediği iki dünya savaşı arasındaki büyük kitlesel göç hareketinin bir benzeriyle bugün, en yoğun haliyle Türkiye’de deneyimliyoruz. Yetmiş yıl sonra dahi güncelliğini yitirmediğini gördüğümüz bu devletsizlik açıklaması, devam etmekte olan mülteci krizinin yarattığı devletsiz neslin çocukları için kuramsal bir çerçeve sunabilir.

Arendt, Totalitarizmin Kaynakları adlı çalışmasının, yine totalitarizmi besleyen bir hareket olarak gördüğü Emperyalizm’e ayrılan kısmında, "Ulus-Devletin Çöküşü ve İnsan Haklarının Sonu” başlığı altında devletsizlerin konumunu ele alır (Arendt, 2014, s. 255). ${ }^{9}$ Arendt'e göre, iki dünya savaşı arasında beliren bu fenomen, her ne kadar savaşla birlikte ortaya çıktıysa da, aslında kökenini daha eski bir insan tasarımında bulur; 1789 İnsan ve Yurttaş Hakları Bildirisi’nin insan tasarımı. Bildirinin ilk üç maddesi, soyut insan tasarımı ve onun ulus ile ilişkisini anlamak için önemlidir:

Madde 1 İnsanlar, haklarında özgür ve eşit doğar, ve öyle kalırlar. Toplumsal farklılıklar ancak ortak faydayla temellendirilebilir.

Madde 2 Her siyasi birlikteliğin amacı, doğal ve devredilemez insan haklarını korumaktır. Bunlar, özgürlük, mülkiyet, güvenlik ve baskıya karşı direnme hakkıdır.

Madde 3 Her egemenliğin temeli, esas olarak ulustadır. Hiçbir bütün, hiç kimse, kaynağını açıkça ulusta bulmayan bir otorite kullanamaz.

Arendt'e göre bu bildirgeyle birlikte şimdiye kadar ilk defa, yasanın kaynağı insan olmuştur; gelenek veya töre değil, uzlaşma ya da tartışma değil, Tanrı’nın belli topluluklara ya da sultanlara verdiği düşünülen ayrıcalıklar hiç değil, XIX. yüzyılda yasanın kaynağı bizâtihi insan olmaktır (Arendt, 2014, s. 293). Bu aslında, hak sahibi olmak için insan olmanın yeterli olması demektir. Bu soyut insan tasarımının doğal sonucu ise, insan haklarının "doğal” ve "devredilemez" oluşudur; doğaldır çünkü doğumla gelir; devredilemez çünkü siyaset üstü bu alanda, her türlü temsil dışarıda bırakılmıştır. İnsan o kadar yalıtık ve soyut tasarlanmıştır ki, artık bu soyut varlığın sahip

9 Özgün İngilizce başlığı "The Decline of Nation-State and the End of the Rights of Men”, "Ulus-Devletin Yıkılışı ve İnsan Haklarının Sonu” olarak çevrilmiş. Görüldüğü üzere “insan hakları” olarak çevrilen "the Rights of Men” aslında, şimdilerde yaygın kullanımıyla İnsan Hakları Evrensel Bildirgesi’nin içerdiği insan hakları değildir. Büyük olasılıkla siyaseten doğruculuk kaygısıyla ve belki de kendisinden sonra gelecek İnsan Hakları Bildirgesi'yle organik ilişkisi bulunduğu için, "insan hakları” olarak çevrilmiş. Çeviriyi eleştirmek yersiz olmakla birlikte bir şeyi görmemizin önüne geçebilir; açıktır ki Fransız Devrimi sırasında insan tasarımı erkekti, diğer bir deyişle insan en nihayetinde erkekti. 
olduğu hakların, korumak için bile olsa, bir üst otoriteye devredilmesi olanaksızdır.

Arendt, tam da bu nedenle XIX. yüzyılın başından İkinci Dünya Savaşı̉nın sonuna kadar, insan haklarının yaygınlaşması için hiçbir kurumun kurulamadığını ve onların korunması için hiçbir yasa çıkartılamadığını söyler (Arendt, 2014, s. 294). Şimdi geldiğimiz noktada insan hakları, BMMYK gibi kendilerini siyasi değil, "toplumsal" ve "insani” yardım kuruluşu olarak belirleyen, yine aynı soyut insan tasarımına dayanarak siyaset üstü ama tek tek ülkelerin siyasi-yasal düzenin insani yönde telkinleriyle düzenleme iddiası olan uluslararası kuruluşlara ve mahkemelere emanettir.

Ancak Arendt bize, İnsan ve Yurttaş Hakları Bildirisỉnin, Birinci Dünya Savaşı sonunda, deyim yerindeyse fiyaskoyla sonuçlanan bir kurgu olduğunu söylemektedir. Bu kurgu, Madde 2 ve Madde 3’e bakıldığında, hatta Arendt'in bu iddiasını destekleyen Agamben’e göre bildirinin başlığına bakıldığında kendini açık eder (Agamben, 2000, s. 19, "İnsan ve Yurttaş Hakları"). Eğer bizâtihi insan olmanın kendisi hak sahibi olmak için yeterli idiyse, bu yurttaşlık da nereden çıkmıştır? Hak sahibi olmak için yurttaş olmak gerekmekte midir? Yoksa bu soyut insan kategorisi, yurttaşlı̆̆ da kapsaması gerekirken, tam tersine yurttaşlık kavramında örtük olarak içerilmekte midir? Arendt bu kurgunun, kitlesel göç hareketleriyle, yurttaş olmayan insanların insan hakkı olmadığını görmemizle birlikte çöktüğünü söyler:

\footnotetext{
"Halk egemenliğiyle insan haklarının birbirinin içinde erimesindeki kuşkulu yan, insanın, ona özgü bir onur olan yeni insan onurunu, daha yüksek ve daha kapsamlı bir düzene atıfta bulunmaksızın sadece bizzat kendisinde bulunmasını sağlayan her türlü otoriteden ve her türlü bağdan kurtulmuş, tamamen yalıtılmış bir varlık olma konumunu, aynı anda bu yalıtılmış durumdan uzaklaşarak bir halkın unsuruna dönüşmesiyle birlikte kaybetmesiydi" (Arendt, 2014, s. 294). ${ }^{10}$
}

Arendt, iki dünya savaşı arasında yaşanan kitlesel göç hareketlerine bakarak doğal ve devredilemez olarak kurgulanan insan haklarının, bir devletin yurttaşlarının hakları olduğunda -aslında başka türlüsü de olanaksız olduğunda- korunaksız kaldığını bir sentezle ortaya koymuştur. Bu bildiriyle birlikte, insan olmak yurttaş olmanın içerisinde soğurulmuş, yurttaş olamayan mülteciler insan kalmaya devam etmiş ancak insan haklarından mahrum bırakılmıştır; gittikleri yerde özgür ve eşit olmamışlar, mülkiyet ve güvenlik haklarından mahrum bırakılmışlardır.

Arendt’e göre bu bir paradokstur çünkü ulus-devlet düzeninin dışında ve üstünde tanımlanan hak sahibi insan, bu düzenin dışına çıktığı anda çırılçıplak kalmıştır; "Anayurtlarında ayrıldıklarında artık yurtsuzdular; devletlerini bıraktıklarında artık devletsizdiler; insan haklarından yoksun bırakıldıklarında artık haksızdılar, yeryüzünün posasiydilar" (Arendt, 2014, s. 256). ${ }^{11}$

10 Burada aslında halktan kasit ulustur; halkın ulus olarak tasavvur edilmesidir.

11 Buradaki 'haksızlık', İngilizcede 'rightlessness' olarak ifade edilen hak mahrumiyeti anlamındaki haksızliktır. 
Agamben, Arendt'in çözümlemesi bir adım ileri taşıyarak, doğum ve ulus egemenliği arasındaki etimolojik bağı gösterir. Bildiri’nin ilk iki maddesi, "çıplak insan”ı siyasi düzene yedirmiş, Madde 3 ise, egemenliğin ilkesini ulusla sınırlamıştır" (Agamben, 2000, s. 20). İnsanı, salt doğmuş olduğu için haklarla donatan Madde 1, aslında ulus-devlet siyasi örgütlenmesindeki egemenlik ilkesini doğum ile belirlemenin ilk adımıdır. Türkçe'de ulus diye ifade ettiğimiz, İngilizce’de "nation” kavramına denk gelen terim, Latince "doğum" anlamına gelen natio kelimesinden türemiştir. ${ }^{12}$

Agamben, Madde 3'ün, egemenliğin ilkesini ulusa dayandırdığını, ulusun (natio) da Madde 1'de hakların temelinde olan doğum olduğunu aksiyomatik olarak egemen otoritenin nasıl kurgulandığını ortaya koyar; doğum, ulus olarak varlığa gelir. Öyle ki, iki moment arasında fark yoktur; doğmakla bir ulusa dahil olursunuz. Doğum ve ulus aidiyeti eş zamanlıdır. Dolayısıyla insan, insan olduğu için değil, bir ulusa dahil olduğu kadar hak sahibidir (Agamben, 2000, s. 20). ${ }^{13}$ Burada 1789 Bildirisi'nin kurguladı̆̆1 gibi bir kendindelik değil, düpedüz ölçü ve koşul mevcuttur. Kitlesel göç hareketleri ise bu kurgunun iflasıdır. Agamben'in deyişiyle, "[e]ğer mülteci, ulus-devlet düzenindeki böylesine rahatsız edici ögeyi temsil ediyorsa, bu onun insan ve yurttaş arasındaki özdeşliği kırarak egemenliğin olağan kurgusunu krize soktuğu içindir” (Agamben, 2000: 20). Agamben haklıdır; bu yazının başında bahsi geçen Siba’nın hiçbir devletin yurttaşı olmadığı için doğduğu halde insan hakkı olmaması, onu "insan ve yurttaş arasındaki özdeşliği” kıran bir figür yapar. Aslında Siba mülteci bile değildir, sadece devletsizdir. Siba’nın yurttaşlığa kabul prosedürüne başvuru bile yapamaması, onun varlığının yok hükmünde olduğunun ispatıdır.

Siba'yla birlikte on binlerce Suriyeli çocuk aynı durumda. Bir örnek daha verecek olursak, Abdoulla ve Marah iç savaştan Türkiye’ye kaçıp burada resmî değil de, geleneksel bir törenle evlenmiş bir çift (Osborne ve Russell, 2015). Marah hamile ve doğacak çocuğun devletsiz olacağını biliyor. Eşiyle birlikte Suriye’ye gidip, çocuğunu orada dünyaya getirmeyi, kimlik aldıktan sonra geri dönmeyi düşünüyor. Ancak Abdoulla, Suriye rejim askerlerinin kendisini öz vatanını terk etmek suçundan göz altına alabileceğinden endişeleniyor. Marah ise tek başına Suriye'ye gidip babasının kimliğiyle bebeğine kimlik almayı düşünmüş ama bu sefer de başka bir yasal engele takıllyor çünkü Suriye iç hukuku gereği anne babanın izni olmadan tek başına çocuğunu ülke dışına çıkaramıyor. Dolayısıyla Marah çocuğuna kimlik çıkartma ve çocuğuyla birlikte Suriye'de savaşın ortasında sıkışıp kalma arasında ahlaki bir dilemmayla karşı karşıya; Marah’ın çocuğu Türkiye'de kalırsa, doğmuş olmasıyla devletsiz olacak; Suriye’ye giderse, çocuğun kimliği olacak ama büyük olasılıkla geri dönemeyecek.

Agamben'in, Arendt'in insan haklarının paradoksal kuruluşunu açığa vurmasını etimoloji desteğiyle bir adım ileri taşıması, bu makalenin başındaki jus soli ve jus sangui-

12 Chicago Üniversitesi Latince -Yunanca sözlük, 'natio' maddesi; http://logeion.uchicago.edu/index.html\#natio

13 Burada Agamben ile Arendt arasındaki farkı vurgulamak gerekir; Arendt 1789 Bildirgesi'nin Batı siyaset kavrayışında bir dönüm noktası olduğunu söylerken, Agamben buradaki egemenlik tasarımının Batı siyasi tarihi kadar eski olduğunu söyler. 
nis ilkeleri açısından anlamlıdır. Bu ilkeler, ulus-devlet modelinde yurttaşlık hakkının halen doğum ile düzenlendiğini gösterir. Suriyeli Siba’nın doğmuş olmakla, hak sahibi olmadığı ortadadır.

Mülteciler ve devletsizler arasında onların yaşam koşullarına bakarak ayrım yapmak, o gün de bugün de çok zor olmakla birlikte mülteci teknik olarak devletsiz insan değildir. ${ }^{14}$ Mülteciden farklı olarak devletsiz kategorisi, birey ile devlet arasındaki bağ olan uyruk (nativity) yokluğuna işaret ettiği için bu kategorideki insanlar tam bir belirlenemezlik alanında, bu makaleye başlığını veren haberin ifadesiyle limboda konumlanmıştır.

\section{Yoksulluk ve Hak Mahrumiyetinin Konumlanışı: Toplumsal olan - Siyasal Olan}

İkinci Dünya Savaşı sonrası insan hakları normlarının dünya çapında değer kazanması ve uluslararası kuruluşların, devletleri denetlemek için iyi birer araç haline gelmesiyle birlikte insan haklarının büyük yol katettiği doğrudur. Ancak bugün tanıklık ettiğimiz türden kitlesel göç hareketlerinde, örneğin Siba’nın hukuki durumunun ne olacağı halen muğlaktır. Söz gelimi kendini LGBT kimliğiyle tanımlayan birey, Avrupa ülkelerine sığınma talebinde bulunduğunda, uluslararası organizasyonların ulusal yasalara tanıştırdığı normlar işlerlik kazanmakta ve "insan"dan yana hükümlerle s1ğınma talepleri çok yüksek oranda kabul edilmektedir. Ancak karşı karşıya olduğumuz mülteci krizinin, kendi içinde tek tek bireylerin sorunları ele alınamayacak kadar kitlesel olduğundan, insan haklarının, Arendt'in ilk formüle ettiği paradoksal haliyle kalmış olduğunu söylemek yanlış olmaz. Siba’nın durumu, Arendt'in "devlet-ulus-toprak" troykasında gördüğü insan hakları paradoksunu doğrular niteliktedir.

Siba’nın durumuna tekrar bakacak olursak, cinsiyet temelli ayrımcılığa dayalı Suriye medeni hukukundan ötürü Suriye uyruğu alamayan Siba’nın annesi, Siba için Almanyåda yurttaşlığa kabul işlemine başvuru yapıp, yasal süreci başlatamıyor. Suriye iç hukukunun, uyruk aktarımını sadece erkeğe (babaya) vermesi, bu kadar büyük ölçekte devletsiz bir neslin oluşumuna yol açmaması gerekir diye düşünenler olacaktır. Ancak sorun, yukarıda açılandığı gibi, kadınları da kapsayan ve kadınları daha derinden

14 Günlük dilde birbirlerinin yerine kullandığımız göçmen (migrant), kaçak ya da kayıt dışı göçmen (undocumented migrants), mülteci (refugee) ve sığınmacı (asylum seeker) arasında belli farklar var. Birleşmiş Milletler Mülteciler Yüksek Komiserliği (BMMYK) en çok karıştırılan ikisine, mülteci ve göçmen kategorilerine şöyle açıklık getiriyor; mülteciler, yaşadığı ülkedeki silahlı çatışma ve zulümden kaçan, güvenlik arayışıyla sınır ülkelere kaçan ve evlerine geri dönmeleri çok tehlikeli olmakla birlikte, dönseler dahi önceden yaşadıkları evlerinden farklı yerlerde barınmak zorunda kalacak olan insanlardır. Bu insanların sığınma talebinin reddi, yüksek olasılıkla ölümcül sonuçlar doğuracaktır. Sözleşmenin tarafı olan devletlerin mültecilere sağlaması gereken temel insan haklarını tanımlayan 1951 Mülteci Sözleşmesi’nin temel ilkelerinden biri, mültecilerin yaşam ve özgürlüklerinin tehlike altında olduğu yerlere geri dönmeye zorlanamayacaklarıdır. Göçmen ise, direkt ölüm tehlikesinden ziyade, yaşam şartlarını iyileştirmek, bazan eğitim bazan da aile kurmak amacıyla, aslında daha kapsayıcı bir ifadeyle daha iyi bir yaşam amacıyla göç etmeyi tercih eden insandır. Eve dönmeleri tehlike arz eden mültecilerin aksine, göçmenlerin geri dönmek gibi bir engeli yoktur; dönmeleri halinde kendi vatanlarında güvenlikli bir yaşam sürdürebilirler. (Edwards, 2015) BMMYK tanımlarına göre Türkiye’deki Suriyeliler'in, silahlı çatışmalardan dolayı ülkesini terk ettikleri için "mülteci” kategorisinde kabul edilmeleri gerekir gibi görünüyor. Ancak Siba’nın uyruğu olmadığı için devletsizdir. 
etkileyen, çözümünü toplumsal ve insani organizasyonlarda değil, ancak siyasette bulacak çok daha derin paradoksal bir insan hakları sorunudur. Tek tek mülteciler için hâlâ işlevsel olabilen uluslararası organizasyonların, kitlesel göç hareketlerinde etkisiz ve kısır kaldığına 2011 yılından bu yana bizzat şahit oluyoruz. Devletsiz insanların yasal yollardan istihdam edilemediğini, mülk sahibi olma haklarının olmadığını göz önünde bulundurduğumuzda, aralarında yoksulluğun da bulunduğu toplumsal sorunlar hak mahrumiyetinin öncelediği sorunlardır:

\section{"[...]bu grupların durumu, olaylar karşısında toplumsal statülerini, çalışma olanakları- nı ve mülk sahibi olma haklarını yitiren mülksüzleştirilmiş orta sınıflardan, işsizlerden, küçük rantiyelerden, emeklilerden de kötüydü: Devredilemez diye düşünülen, hatta öyle tanımlanan haklarını, yani insan haklarını yitirmişlerdi” (Arendt, 2014, s. 258).}

İstatistiksel verilere bakmaksızın, sadece etrafımıza bakarak, Suriye mülteci krizinin Suriyeli aileleri topyekün yoksulluğa mahkum ettiğini söylememizde sanırım hiçbir sakınca yok. BMMYK ve diğer insani yardım kuruluşları, Suriyeli ailelerin dehşete kapılmış ve tüm birikimlerini tüketmiş olarak ülkelerinden kaçtıklarını belirtiyor. BMMYK raporları aynı zamanda, Suriyeli ailelerin iki yılı aşkın süredir kaçmakta olduğunu, vatanlarını terk etme kararlarını alamadan önce bile, bir yerden diğerine taşındıklarını yani aslında daimi seyyar bir halde Suriye sınırları içinde var kalmaya çalıştıklarını tespit etmiştir. Aileler bu durumdayken, eşlerini kaybetmiş yalnız kadınlar ise çocuklarına bir başına bakmak zorunda (Reardon, 2014).

Bu noktada bir yol ayrımına geliyoruz: Kendisini toplumsal ve insani olarak tanımlayan BMMYK’nın yaptığ da yoksulluk sorununun toplumsal bir sorun olduğunu teslim edip çözümünü bulacağ1 alan üzerinden yani "siyasal olan” üzerinden devam edebiliriz, çünkü Arendt'in çözümlemesinde gördüğümüz gibi, ulus-devlet düzeninde devletsizlik otomatik olarak hak mahrumiyetini beraberinde getiriyor ve bu, toplumsal değil siyasi bir sorundur. İlk yol değersiz olmamakla birlikte çözümsüzdür. Ancak bu, uluslararası insani kuruluşların ya da iktisat gibi disiplinlerin yoksulluğu konu edinemeyeceği anlamına gelmez.

Saf ekonomik anlamda gelir yoksulluğu, tek tek ülkelerin belirli parametrelere göre belirlediği sayısal eşiğin altında kalan aile gelirini tanımlamak için kullanılan bir ifadedir ve özellikle bireyin değil, aile gelirini ölçü alır. Başka bir yoksulluk türü ise aşırı yoksulluk, yani günlük 1 dolar altındaki kazanç miktarını tanımlamak için kullanılır. Birleşmiş Milletler Kalkınma Programı zamanla bu tanımları detaylandırmış ancak gıda, giyim ve barınma gibi temel ihtiyaçları karşılayabilecek para miktarına karşılık gelen mutlak yoksulluğun yanına göreli yoksulluk tanımını getirmiştir. BM Eğitim, Bilim ve Kültür Örgütü (UNESCO), mutlak yoksulluğun yaşam kalitesi ve toplum içindeki eşitsizlik gibi sorunları kapsayamadığı, bireyin "önemli toplumsal ve kültürel ihtiyaçları" olduğuna kanaat etmiş ve yoksulluğu "toplumun diğer üyelerinin ekono-

15 The Guardian'ın yine bir Suriye mülteci kriziyle ilgili haberinde, satır arasında göze çarpan BM’nin 18 ay önce istatistik veri toplamayı bile bıraktığı bilgisi şaşırtıcıdır (Black, 2016). 
mik statüsü” ile karşılaştırma yoluyla daha kapsamlı bir şekilde tanımlama yoluna gitmiştir. Göreli yoksulluk tanımına göre insanlar, belirli bir toplumsal bağlamdaki yaygın yaşam standardının altında kaldıkları sürece yoksuldur. ${ }^{16}$

UNESCO’nun mutlak ve göreli yoksulluk arasında yaptığı ayrım, yüzyıllardır değişmeyen bir kaygıya dair önemli bir ipucu verir. Temel ihtiyaçlar baz alınarak tanımlanan mutlak yoksulluk insanın salt biyolojik yaşamıyla ilişkilendirilirken, yaşam kalitesi kaygısıyla yapılan göreli yoksulluk tanımı, insan yaşamının toplumsal tarafının da vazgeçilmez bir şekilde ekonomik ilişkilerle belirlendiğini kabul eder. Bu tanımların belirli işlevleri olduğu elbette doğrudur ama en nihayetinde ölçüme dayalı nicel tanımlardır; mutlak yoksulluk 1 dolar, aşırı yoksulluk 1 dolar altı, göreli yoksulluk ise adının da ima ettiği gibi toplumsal bağlama göre hesaplanır. Buna karşın, aslında insan yaşamının ne biyolojik ne de toplumsal olana indirgenemez, yani ölçülemeyen ve hesaplanamayan ama yine de farklı bir biçimde de olsa yoksullukla ilişkilendirilebilecek siyasi bir yanı vardır.

XX. yüzyılın ilk çeyreğinden bu yana siyaset felsefesinin, en etkili kuramlara sahip figürleri Adam Smith ve Karl Marks’tan miras kalan siyaset anlayışını geride bırakma girişimlerine tanık oluyoruz. Bu çağdaş kuramsal girişimler esasında, insanın salt sosyoekonomik veya ekonomi politik ile açıklanamayan potansiyel bir yaşam formuna sahip olduğunu gösterme çabasının yanı sıra, siyasetin kendisinin indirgenemezliğini ve böyle olmakla insan için biyolojik yaşamın ötesinde bir yaşamsallık teşkil ettiğini gösterme çabasıdır. Dolayısıyla siyaset felsefesi XX. yüzyılda, tarihi boyunca hiç olmadığı kadar siyasetin ne olduğu sorusunun peşinde olmuştur.

Siyasal olanı, yani siyasetin saf ve indirgenemez karakterini felsefece masaya yatırmış olan Arendt, İkinci Dünya Savaşı’nın getirdiği buhranla birlikte haklı olarak liberal ve sosyalist kuramlarının iflas ettiğini düşünür. Ona göre bu kuramların açıklama gücüne bırakılmış insan yaşamı siyasetle yeniden ama farklı biçimde tekrar ilişkilendirilmelidir.

Arendt'in insan yaşamını yeniden düşünmesi, onu çağdaş kuramların yaşam düşüncesinden gerilere, Yunan filozof Aristoteles'e kadar götürmüş ve Antik Yunan dünyasının yaşam anlayışında, bizimkinden çok farklı bir ayrım keşfetmiştir; bios politikos. Aristoteles'in kendisinden alıntılayacak olursak, "İnsan, tam gelişme durumuna ulaştığında yaratıkların en iyisi, ama yasa ve adaletten ayrılınca en kötüsü olur” (Barnes, 2014, s. 1253, a19-39). İnsanın, diğer mahlukatla kıyaslandığında kendi türüne özgü bir aralığı mevcuttur. Aristoteles'e göre belirli bir aralıkta yaşayan insan, yaratıkların en iyisi de olabilir en kötüsü de... İnsana özgü ontolojik aralıktan düştügüünde, örneğin aşırı yoksulluk koşullarında, insan pek de insana benzemeyebilir. Agamben de, yaşamı ifade etmek için iki ayrı kavram olan, yine insanın yaşadığı aralığı belirleyen Yunan düşüncesinin ayrımına dikkat çeker; bios ve zoē (Agamben, 1998, s. 1). Zoē, in-

16 UNESCO, yoksulluk tanımı için

http://www.unesco.org/new/en/social-and-human-sciences/themes/international-migration/glossary/poverty/ 
sana verilmiş olanın, yani nefes alabilme ya da ancak yemek yiyebilirse var kalabilme gibi hayvanlarla paylaştığı zorunluluk alanının sınırlarını çizerken, bios, formu olan bir yaşam yani doğanın, insan için doğal olanı karşılayıp onu zorunluluklar alanından dışarıya ittiği yerdir. Antik Yunan düşüncesinde zorunluluklarından sıyrılmış "iyi yaşam” tam da burada konumlanır.

Yaşamın devamı için yeme-içme gibi günlük zorunlu ihtiyaçların karşılanması örneğin bir hayvana yapılabilecek en iyi şeydir çünkü onu tatminkâr kılar, ama insana yapılabilecek en kötü şeydir. İnsanı zorunluluklar alanında tutmak onu hayvan yapmaz, ama tür olarak başka bir şeye dönüştürebilir. İnsanın, doğanın ona verdiğini kullanıp, doğal belirlenimlerinin ötesine geçme, iyiye doğru gitme kapasitesi vardır. Bu olanak kapatıldığında, zoē alanına düşer. Yoksulluk da insanı belli bir eşiğin altına sokarak onu zoē alanına düşürebilir. Belki de bazan, "İnsanlığa sığmaz!", "İnsan insana bunu yapar mı!” diyerek ettiğimiz isyan, insanın yasa ve adaletten ayrılması sonucu dönüştüğü şeye ettiğimiz isyandır. "Çıplak yaşam” in sürdüğü $z o \bar{e}$, tekrarlayan ve döngüsel bir alandır ve "salt" zorunlulukla devam eden hayat tarzının bios politikos ile hiçbir ilgisi olamaz (Arendt, 1994, s. 26). Aristoteles'in bu ayrımı, yasa ve adaletin, insanın doğal olan ile ilişkisine ölçüt getirmesi anlamında çok önemli bir yer teşkil eder.

Aristoteles'e göre yasa ve adalet bizim uylaşımlarımız, üzerinde anlaştığımız ilkelerdir. İnsan siyasi etkinlikte bulunarak uylaşımlara varır. Bu nedenle Antik Yunan dünyasında siyasi etkinlik, bios ve $z o \bar{e}$ aralığında yaşayan insanın hayati bir etkinliğiydi. Modern dönem de ise, 1789 Bildirisi’ne geri dönecek olursak, Antik Yunan dünyasından oldukça farklı bir insan anlayışına rastlarız; Madde 1; insan doğmuş olmakla eşit ve özgürdür. Oysa Arendt'in özellikle Aristoteles ve Yunan düşüncesine bakarak söylediği gibi, insan doğmuş olmakla ne özgür ne de eşit olur; ancak ve ancak yaşamın üst etkinliği olan siyasetle özgür ve eşit olmaya doğru gidebilir; "Eşit olarak doğmayız; karşılıklı olarak eşit haklara sahip olduğumuzu birbirimize garanti etme doğrultusundaki kararımıza güvenen bir grubun üyeleri olarak eşit hale geliriz” (Arendt, 2014, s. 312). Kadın ve erkek, mülteci ve yurttaş, Suriyeli ve Türkiyeli eşit doğmazlar. Ama zaten tam da eşit olmadığımız için eşitlik istemez miyiz? Dolayısıyla eşitlik bize türlü bildirgelerin söylediği gibi verili değildir; onu hayati etkinliğimiz olan siyasetle alırız.

Yine Madde 2'de, "her siyasi birlikteliğin amacı, doğal ve devredilemez insan haklarını (özgürlük, mülkiyet, güvenlik) korumaktır” demektedir. Bu, Arendt için skandal nitelikte bir maddedir çünkü siyaset "doğal ve devredilemez" olduğu düşünülen bir kurgunun sürdürülmesine indirgenmiştir. Diğer bir deyişle siyaset, siyasi olmayan bir alana çekilmiştir. Antik Yunan düşüncesinin deyişiyle siyaset, doğal olana yani $z o \bar{e}$ (çıplak yaşam) alanına düşmüştür. Tam da bu nedenle doğum, yurttaşlıktan ayrı düşünülemez; doğum, tek başına insan haklarını koruyamadığı için aynı bildiri eş zamanlı olarak ulus aidiyetini tanıştırmak zorunda kalmıştır.

Başlı başına insan varlığını kendisine dayanan insan hakları, ilk defa her türlü niteliğini ve ilişkisini kaybetmiş ve "insan olmanın ve insan olmaktan başka hiçbir şey 
olmamanın soyut çıplaklığından” sıyrılamayan devletsizler için işlevsizdir (Arendt, 2014, s. 305). Bugün Suriyeli kadınlar ve aileler yoksulluk içinde $z o \bar{e}$ alanında var kalmaktadır (survival). Günlük dilde kullanıldığı şekliyle “insani ihtiyaçlar”, Arendt'in Antik Yunan düşünce dünyasında gördüğü şekliyle, aslında hayvansal-biyolojik ihtiyaçları dile getirmektedir. Ona göre, siyasetin indirgendiği bu skandal yerin işgalci bir doğası vardır; Antik dönemde özel bir alan olan hanenin idaresinin (oikos-ekonomi) zaman içinde tüm kamuyu işgal etmiştir. Sadece insan olan, başka da bir şey olmayan soyut insan tasarımının işgal ettiği hak kavramı, kendisine ancak toplumsal olanı konu edinen, aslında idareden başka bir şey olmayan amorf bir siyaset anlayışını beraberinde getirmiştir.

Arendt, Antik Yunan dünyasında hane idaresi (oikos) ve şehir (polis) ayrımının, modern dünyanın özel ve kamusal ayrımından çok farklı olduğunu söyler. Antik dönemin özel alanı olan hane idaresini, eşit ilişki değil, tersine tabiiyet ilişkisi belirlerdi; "Hanenin ayırt edici özelliği, insanların burada istek ve ihtiyaçların güdümünde bir arada yaşıyor olmalarındaydı” (Arendt, 1994, s. 49). Kamusal alan agoranın merkezde bulunduğu polis ise, zorunluluk alanına giren "istek ve ihtiyaçların” ötesinde, bunların tatmininden sonraki bir üst alan olan özgürlük ve siyaset alanıdır.

“Antik Yunan düşüncesine göre tam da 'politik ekonomi' tabirinin daha kendi içinde çelişkili olacağı aklımıza bile gelmiyor; 'ekonomik' yani bireyin hayatı ve türün bekasıyla ilgili olan, tanımı gereği siyasi-olmayandır, yani haneye ait bir meseledir” (Arendt, 1994, s. 48).

Antik Yunan siyasi düşüncesinin tersine modern idare, "toplumsal olan”ın kamusal alanı işgal etmesidir. Modern bilinç için ulus, "süper-insanlık ailesi” ya da "ekonomik olarak örgütlenmiş aileler topluluğu” gibi özel alanın kamusal alanla iç içe geçtiği, aslında çok kritik olan bir ayrımın muğlaklaştığg bir alanda hayat bulur (Arendt, 1994, s. 48). ${ }^{17}$ Arendt'e göre, "özel çıkarların kamusal ehemmiyet kazandığı adına "toplum" dediğimiz bu tuhaf melez alan siyasetin içinin bütünüyle boşaltılmasıyla sonuçlanan bir bürokratik idarenin konusu olmuştur (Arendt, 1994, s. 55). Bundan daha da kötüsü, tüm bunlar eşitlik adına yapılmaktadır.

Peki, zorunlulukla belirlenen bu özel alanın, toplumsallık olarak yükselmesi, sosyoekonomik bir sorun olan yoksulluğu Arendt'in öne sürdüğ̈̈ gibi, sırf kamusal alanın konusu değildir diye siyasetin konusu yapma kaygısından vaz mı geçmeliyiz? Belki zor bir soruyla konuyu daha da girift hala getirmek olanaklı; insan ihtiyaçları arasından hangileri zorunludur? Yoksulluğu ölçmek için Birleşmiş Milletler Kalkınma Programı’nın sunduğu İnsani Yoksulluk Endeksi'ne baktığımızda her yıl biraz daha genişleyen sayısız parametreyle karşılaşırız; ${ }^{18}$ beslenme, barınma, giyim, güvenli içme

17 Eserinin çevirmeni, "nation” terimini “millet” olarak çevirmiş. Kanımca burada "ulus" karşılığı daha uygun olurdu çünkü "millet” çok daha çoğulcu, tarihsel ve siyasal bakımdan özel içerimleri olan, ulus-devlet modelinden çok imparatorluk sistemindeki halk düşüncesine karşılık gelen bir kavramdır.

18 Yoksulluk parametreleri öyle genişlemiştir ki, yönetime katılım, temel insan hak ve özgürlüklerinin sağlanması, sosyal güvenliği olan bir işte çalışma gibi başlıklar dahi artık yoksulluk ölçümü içerisine alınması gerektiği 
suyu, kanalizasyon, elektrik, sağlık, eğitim ve seyahat gibi hizmetlere ulaşım. Toplumsal olanın konusu olan "birey" in ${ }^{19}$ zorunlu ihtiyaçları gittikçe genişleyen bir alana yayılmaktadır. Göreli yoksulluk ölçümündeki oransal ifadelerle, parametrelerin gittikçe inceltildiğini görürüz; kırk yaşından önce ölme riski taşıyanların oranı, sağlıklı içme suyuna erişimi olmayanların oranı, sağlık hizmetine erişim olmayanların oranı, beş yaş altı çocuk ölüm oranı vb. Bu başlıkların hepsi, Aristoteles'in deyişiyle insan olarak aynı aralıkta yaşadığımız mülteciler için de geçerlidir. İşte Arendt tüm bu başlıkların kamusal alanı işgal ettiğini, eşit ve özgür yurttaşlardan ziyade idare edilmesi gereken bir ulus nüfusunun sorunları olarak görüldüğü için siyasetin bürokrasiye dönüştügünü öne sürüyor. Arendt'in bize sunduğu çerçeveden bakarsak, insan ihtiyaçlarının zorunlulukla karakterize olmuş ve böyle olmakla toplumsal alana ait bu konular siyasetin konusu olamayacak mıdır? Eğer olacaksa, siyaset insan ihtiyaçlarının dökümünden mi ibaret olacaktır?

\section{Yoksulluğun Temsili}

Arendt'in, "toplumsal olan" (the social) ve "siyasal olan" (the political) arasinda yaptığı ayrım birçok araştırmacının sorunlu gördüğü bir ayrımdır. Arendt'i entelektüel olarak derinden etkileyen Antik Yunan şehir-devlet yapılanmasının, sosyoekonomik sorunların politikleştirilmesi konusunda modern döneme esin kaynağ olmasının pek de olanaklı olmadığı, yeni toplumsal sorunların çözümlerini eskide aramanın nafile ve romantik bir çaba olduğu pek çok kere dile getirilmiştir. Örneğin, Arendt'in toplumsal olan kavramını masaya yatıran Hanna Pitkin, "toplumsal olana açık ve olabildiğine geniş yer veren kurnaz yorumcular, toplumsal olanın iktisat ve normalleşmeyi de içeren karmaşık bir bileşim olduğunu görmüş" olduğunu ileri sürerek, bu ayrımın karşı-argümanlar karşısında kırılganlaştığını öne sürer (Pitkin, 1998, s. 17). ${ }^{20}$ Yahut Heller'e göre, toplumsal alana dahil bu sorunlar bu kadar karmaşık ve yığılı kalırken, Arendt' in siyaset kuramı hiçbir kesimi dışlamaz, çoğulcudur ama "bazı konuları” dışlar (Heller, 1990, s. 119).

Peki Arendt'in siyaset kuramında geriye siyaset için ne kalır? İnsanın zorunlu insan ihtiyaç listesini kamuya tahvil eden bu modern anlayış içinde, ama aynı zamanda Arendt' in bize sunduğu çerçeve içinde kalarak, yoksulluk gibi toplumsal sorunun modern siyaseti olanaklı mıdır? Siyaset bilimci Ayten Gündoğdu son kitabında, farklı bir Arendt okuması yaparak bunun bir olanağı olduğunu ileri sürüyor. Gündoğdu'nun, Arendt' in toplumsal olan okuması, kendi ifadesiyle "Arendt'le birlikte Arendt'e karşı" bir okuma. Dolayısıyla aynı zamanda, Arendt'in insan haklarında gördüğü kapanmaz gedikleri kapatmanın bir yolunu da sunuyor ve insan hakları siyaseti olanaklı hale geliyor. Ne var ki, Gündoğdu'nun sunduğu Arendt okuması önemli bir kapıyı aralasa da, kanımca, kitlesel göç hareketleri için insan hakları siyasetine olanak tanıyamaz.

düșünülmektedir.

19 Arendt’e göre toplumsalın öznesi birey, siyasetin öznesi ise kişidir (persona).

20 Pitkin burada özellikle Margaret Canovan’a gönderme yapıyor çünkü Arendt’in toplumsal olan kavramı onun için, "iç tutarlılıktan yoksun" ve "kesinlikle tatmin edici bir senteze varılamayacak kadar yığılmış bir kümedir." 
Yine de Gündoğdu'nun toplumsal bir sorun olan yoksulluğun siyaset alanına dahil edilebilmesi konusunda yaptığı çözümleme dikkate değer. Gündoğdu, Arendt'in toplumsal olan anlayışının çok katı olduğunu kabul eder ancak esasında onun, toplumsal sorunların siyasete dahil olmasında değil de, siyasallaştırma (aslında siyasallaştıramama) biçiminde sorun gördüğünü, Arendt'in Fransız ve Amerikan Devrimi çözümlemelerine bakarak çözümler. Gündoğdu, Arendt'in görece arka planda kalmış Devrim Üzerine kitabına yoğunlaşarak bu iki devrim arasındaki kritik bir farklıllğa dikkat çeker; Arendt'e göre ne Fransız Devrimi ne de Amerikan Devrimi yoksulluk sorununu siyasetin konusu edebilmiştir. Fransız Devrimi yoksulluğu devrimin merkezine koyarak, Amerikan Devrimi ise neredeyse bütünüyle görmezden gelerek yoksulluğu siyasal olanın dışında bırakmıştır. (Gündoğdu, 2015, s. 67). ${ }^{21}$

Gündoğdu’nun kapsamlı çözümlemesine göre, Arendt için Fransız Devrimi’nin, devrimci bir terörle yıkıcı bir şekilde sonlanmasının nedeni, devrimin simgesi Sans-Culottes (pantolonsuzlar) figüründe görüleceği üzere, yoksulluğun kamusal alanın tam da merkezine koyulmuş olmasıdır. Bu figür, halkın yoksul emekçi kesiminin siyaset alanını tümden işgal etmiş olduğunun göstergesidir. Bu figürle birlikte, devrimcilerin amacı, yoksullarla onların temsilcileri arasındaki ekonomik farkın kapatılmasına indirgenmiştir. Burada yoksulluğun, Arendt'in ünlü ifadesini hatırlayacak olursak, "özel çıkarların kamusal önem arz ettiği” melez bir alan olarak toplumsallı̆̆ın içinde konumlandığını görebiliriz. Gündoğdu için bu, tam da Arendt'in kaygısı olan toplumsal olanın siyasal olanı işgal etmesinin isabetli bir örneğidir; toplumun belirli bir kesimi olan pantolonsuzlar, kendileri için istedikleri ekonomik eşitliği tüm kamuya tahvil etmekle aslında kamuyu kendi toplumsallıklarıyla doldurmuşlardır. Dolayısıyla Fransız Devrimi’nde “özel alanı kamusal kaygıya dönüştüren temsili pratikler” başarısızlıkla sonuçlanmıştır (Gündoğdu, 2015, s. 66). Bu temsil pratiği, pantolonsuzları, içlerinde ayrım yapılamayacak kadar büyük bir kitle olarak "acı çeken bedenler" ya da "kurbanlar" biçiminde sunmasıyla, hak taleplerinin siyasi talep olarak kamuya taşınmasının önüne geçmiş ve siyaseti daraltmıştır (Gündoğdu, 2015, s. 70). Agamben'in deyimiyle, devrimciler salt çıplak yaşamlarıyla $(z o \bar{e})$ kamusal alana çıkmıştır.

Gündoğdu’nun dikkat çektiği "temsil pratiği”, özel alanın kamusal kaygıya dönüştürülmesinde siyaseten çok önemli bir noktaya işaret ediyor. Yoksulluğun yıkıcılığını en çıplak haliyle gördüğümüz Suriye mülteci krizinde de, aslında benzer bir durumla karşı karşıyayız. Acılar içindeki aileler, çıplak ayaklı çocuklarıyla anneler, ya botların içinde ya da Lübnan'da çölün ortasında çekilmiş resimleri... Gündoğdu’nun işaret ettiği bu temsil pratiği, içeri almak isterken dışarıda bırakan ve kendini faydacı bir hesapta gösteren bir eğilim taşır. Amerika’da, sözüm ona mültecilerin dışlanmaması için yürütülen kampanyalar arasında "Steve Jobs Suriyeli bir mülteci çocuğuydu. Cumhuriyetçiler mülteci kabul etmemeliyiz dediklerinde bunu hatırlayın” posterleri buna örnektir; Steve Jobs'in mülteci figürüne benzetilerek resmedildiği bu posterlerde, Suriyeli mülteci belirli bir fayda yani Jobs’ın Amerika’ya kazandırdığı markanın

21 Kanımca Arendt'in bu çözümlemesi, Fransız siyasi geleneğinin eşitlikçi cumhuriyet fikriyle karakterize olmasını, Amerikan siyasi geleneğinin ise daha ziyade özgürlükçü liberal kalmasını açıklayabilir. 
getirisi üzerinden tanımlanıp toplumun kabulüne sunulmuştur. Bunlar, kendilerini toplumsal ve insani olarak tanımlayan uluslararası kurum ya da gazetecilerin işi olabilir belki ama böyle bir temsilin kendisi siyasal olanın kapsamında değildir. Yoksulluk sorununun siyasetin ortak bir kaygı konusu olarak kamusallığa gerek duyduğu, aksi takdirde kişisel meseleler olarak kalıp unutulmaya mahkum olacağı açıktır. Ancak yoksulluğun kendisini en çıplak ve katışıksız haliyle kamuya taşımak siyasi bir edim olmadığı gibi, klişe deyimiyle "toplumsal farkındalık" yaratma konusunda da ne kadar etkili olduğu muğlaktır. Acı çeken bedenler üzerinden devam eden bir temsil pratiği, acının kolektivize edilişi, kadınların tecavüz "kurbanı" olarak sunuluşu, içinde her zaman arabesk bir topluma yol alma tehlikesini barındırır. ${ }^{22}$

Sonuç olarak, aslında toplumsal bir sorun olan yoksulluk, siyaset zemininde dönüştürülmediği sürece insan yaşamını nasıl da dumur ettiği, ya vicdanları zonklatan fotoğraflarda ya da hep rakamların sıkışı diliyle ifade edilen dokümanlarda kalacaktır. Bu konuda titiz ve dikkatli olmaktan başka bir alternatifimiz yok çünkü Suriye mülteci kriziyle birlikte, devletsizler sorunundan, devletsiz nesil sorununa doğru yol almaktayız. Dolayısıyla her bir mülteci kadına gösterdiğimiz titizlik, aynı zamanda bir kuşağa gösterdiğimiz titizlik olacaktır.

\section{Göçmen Kadınlar ve Türkiye Bağlamı}

İkinci Dünya Savaşı’ndan bu yana yaşanan en büyük trajedi olarak görülen Suriye mülteci krizi, yalnızca BMMYK gibi çok geniş çaplı bir insani yardım kuruluşunu dahi etkisiz bırakmakla kalmadı, aynı zamanda sonuçları itibariyle tüm düşünce kategorilerimizi de alt üst etti. Aradan yetmiş yl geçmesine rağmen Arendt'in devletsiz insan yaşamı çözümlemesi geçerliliğini korumaktadır. Ona göre, insan modern zamana gelene kadar hiçbir zaman, sosyoekonomik veya ekonomi politik modellerin yaptığı gibi, kendini siyasi ortaklığın dışında tasavvur etmedi. Komünal bağları, oradaki ortaklaşa standartları ve ayırt edici siyasi niteliği kaybetmenin, "insanı beşeriyetin dışına" ittiğine kendi gözlerimizle tanık olduğumuz bir süreçten geçiyoruz (Arendt, 2014, s. 306). Kilis’te yaşamını sürdüren mülteci kadın Najlaa, "bize ne oldu?" diyerek şaşkınlıkla soruyor; "Suriye’de güçlü ve cesur bilinen kadınlar burada zamanın geçmesini bekliyor. Biz her şeyi yapabilen kadınlardık oysa ki...” (Unal, 2015). Suriyeli kadınlara ne olduğu açı; siyasi ortaklıklarını kurdukları dokuyu kaybettiler. Najlaa’nın yaşamı diğer kadınlardan farklı; kumaşlarla haşır neşir ve dikiş dikiyor. Tam da kendini, çıplak yaşamın dışına atabildiği için diğer kadınlara bakarak "bize ne oldu?" diye sorabiliyor çünkü çıplak yaşamın içindekiler kendilerine ne olduğunun çok da farkında değildir.

22 Burada yanlış anlamaya mahâl vermek istemem. Acı çeken bir insan tek başına empati yapmaya elbette değerdir, ancak acının temsil pratikleri aracılığıyla kamusallaştırılması, örneğin mülteci bir anneyi toplum gözünde "acıların kadını” yapabilir. Aynı şekilde şefkat kendi başına değerli bir duygudur ama şefkatin kamusallaşması kolektif bir acımayla sonuçlanabilir. Bu duygular kamusallaştığı sürece, siyasetin önünde, insanları pasivize etmesiyle siyasete engel teşkil etme riskini her zaman içinde barındırır. Siyasetin, belki kendine konu ve sorun edindiği başlıklar değil ama, kendisi seçkin ve sofistikedir; aksi halde konu ve sorunlar banalleşecektir. 
Suriyeli mülteci kadınların sürgün hayatı, geleneksel geçim kaynakları ve komünitelerinden uzak yoksulluk içinde devam ediyor; kadınlar yoksullaştıkça çocukları marjinalize oluyor, eşleri (tabii eğer iç savaşta ölmediyse) yasa dışı yollardan para kazanma seçeneğine başvuruyor. Eğer mülteci kadının ne kadar yoksul olduğundan başka bir şey söyleyeceksek, o da mülteci kadını kamusal alanda tekrar görünür kılmanın nasıl olanaklı olabileceğini tartışmak olmalıdır. Yoksulluğu tartıştığımız Arendt'in kuramsal çerçevesinden bakacak olursak, toplumsal ve siyasal olan arasındaki katı ayrımın incelmesinin koşulu, yine siyasal olandadır. Diğer bir deyişle, mülteciler ve devletsizler için, yoksulluktan yani çılak yaşamdan $(z o \bar{e})$ siyasete dönüşü mümkün kılabilecek tek yol, yine siyasetin kendisinden geçiyor. Peki Türkiye siyaseten ne yapıyor?

BM Yüksek Komiserliği'nin Suriyeli mülteci krizine yaklaşımı ve örtük ifadelerle Türkiye’ye verdiği telkinler yani Türkiye’nin kapılarını açıp devlet hazinesinden yaptığı kamplarda yer göstermesi ve Schengen bölgesine geçmelerine izin vermemesi, kurumun gittikçe işlevsizleştiğinin göstergesi gibidir. BM Yüksek Komiserliği Türkiye’nin misafirperverliğini "olağanüstü cömertlik" (Gaynor, 2015) ifadeleriyle betimleyerek, Türkiye’den daha fazla Suriyeli mülteciye ev sahipliği yapmasını beklemesi, krizi daha da büyüteceği gibi, insan kaçakçılarının mesailerini arttırmaktan başka bir faydası da dokunmayacaktır. Bunun yanı sıra, Rus savaş uçaklarının Halep’i vurmasıyla, Türkiye sınır dışında ağırlama kararı aldığı 60-70 bin kişilik, toplamda ise 600 bin kişiye ulaşması beklenen son mülteci dalgasıyla beraber bölgede bir süredir savaşan militanların da gelmiş olabileceği ve bu nedenle mülteci hattının Türkiye için yarattığı güvenlik endişesi BM Yüksek Komiserliğỉnin de paylaşması gereken bir endişedir.

Suriyeliler'in en çok göç ettiği ülkelerin başında "açık kapı politikası" yürüten Türkiye geliyor. Afet ve Acil Durum Yönetimi Başkanlığı (AFAD) son rakamlara ilişkin henüz resmi bir açıklama yapmamakla birlikte, resmî ağızlar Türkiye'deki Suriyeli mülteci sayısının kayıt dışı olanlar da dahil, tahminen 2,7-3 milyon arasında olduğunu belirtiyor. Suriyeli mültecilerin bir kısmı kamplarda yaşarken, diğerleri kentlerde zorlu şartlarda hayatta kalmaya çalışıyor. Bu süreçte, Türkiye’nin göçmen politikası eleştirisinin en önemli başlığı Suriyeden akın akın kaçan insanların hukuki statüsü oldu. Türkiye Suriyeliler'e, "mülteci değil misafir" tanımı getirerek, gerek ulusal hukuk gerekse uluslararası hukukta karşılığı olmayan misafir kategorisi altında ev sahipliği yapmaktadır. ${ }^{23}$ Türkiye başından beri özellikle söz konusu bu misafir kategorisi üzerinden eleştirilmektedir. Eleştiriler, "Daimi misafirlik olur mu?" ya da bu makalenin de konusu olan "Mülteci Krizi Limboda Devletsiz Bir Nesil Yarattı" haberinden yola

23 Türkiye, Kasım 2011'de Cenevre'de gerçekleşen BM toplantısında, Türkiye’ye sı̆̆ınan mültecilere "geçici koruma" rejimi uygulandığını deklare etti ve 2014 yılının Ekim ayında "geçici koruma" yönergesini yayımladı. Kamplarda yaşayan Suriyeliler'in öncelikli olarak, "geçici koruma" ilanıyla gelen "sınır dışı edilmeme hakkı" mevcut. İkincil olarak barınma, gıda ve suya ulaşım, sağlık hizmetleri gibi tüm temel ihtiyaçları karşılanmakta ve eğitim olanakları mevcut. Kamp dışında kayıtsız yaşayanlar bu haklardan mahrum, fakat valiliklerde kayıt altında olanlar sağlık hizmeti alabiliyor. Tüm bunları düzenleyen yönergenin Suriyeliler'e BM tanımları arasında hukuki bir statü vermediği doğrudur. Son olarak, altı aydan fazla süredir Türkiye'de bulunanlara ise, belli koşullar altında çalışma hakkı verecek olan düzenleme getirildi.

http://www.resmigazete.gov.tr/eskiler/2014/10/20141022-15-1.pdf 
çıkarak söyleyecek olursak "Geri dönmeleri mümkün olamayanlar arafta birakılıyor" gibi maksimalist ifadelerden ibaret.

Diğer yandan Türkiye, ulus-devlet tarihinde şimdiye dek görülmemiş XXI. yüzyllın en büyük krizi olan bu olağan dışı kitlesel göç hareketine, tam da Arendt'in siyaset kuramının içinde merkezi bir öneme sahip hak siyasetiyle cevap vermeye hazırlanıyor. T. C. Cumhurbaşkanı Başdanışmanı Mehmet Uçum’un kaleme aldığı "Yurt edinme hakkı' gerçek olabilir mi?” adlı makale, Türkiye egemen siyasi otoritesinin mülteci krizini, uluslararası hukuka bırakılamayacak kadar siyasi bir mesele olarak kavradığını göstermiştir (Uçum, 2016). Başdanışman Mehmet Uçum bu makalesinde, yeni bir hak kategorisinin olanaklı olup olmadığını tartışmaya açarak, krizin hak siyaseti düzlemine çekileceğinin sinyallerini vermiştir. Bu tartışma, Suriye Bağışçılar Konferansı adı altında düzenlenen yardım kampanyalarının topladığı miktarların ötesinde, hâlihazırdaki vatandaşlık hukukunun, Uçum’un ifadesiyle "küresel bireyin ve ait olduğu sosyolojinin mobilizasyon ihtiyacına artık yanıt veremez durumda" olduğunu kendisine konu edebilen, Arendtçi anlamda toplumsal olanın siyasal olana tahvil edildiği bir tartışmadır. Dolayısıyla Türkiye isabetli bir biçimde, göçmen yoksulluğunun siyasi bir sorun olmadı̆̆ı ama yalnızca siyasetin çözebileceği bir sorun olduğu bilinciyle ilerlemektedir.

Agamben, ulus-devlet modelinde kapatılması gittikçe zorlaşan siyasi-hukuki kategorileri göz önünde tuttuğumuzda, mültecilerin, yaklaşan siyasi bir ortaklığın biçimini ve sınırlarını görebileceğimiz, bugünün insanı için düşünülebilir tek figür ve tek kategori olduğunu öne sürer. Agamben'e göre, Arendt'in formüle ettiği paradoksun, insan hakları kavramının süregelen ama hiç bitmeyecek radikal krizi yerine, yurttaşlığa dair hiçbir hakkı olmayan mülteci figüründe somutlaşması gerekir. Ona göre Arendt, krizi eksiksiz formüle etmiş ancak odağını kaydırmıştır; radikal kriz insan hakları kavramında değil, insan yaşamının tam ortasında, mülteci figüründe yatmaktadır:

\footnotetext{
"Bizi bekleyen yeni görevlerde tümüyle eşit olmak istiyorsak, şimdiye kadar siyasal olanın özneleri olarak tasarladığımız (İnsan, yurttaş ve yurttaş hakları, egemen halk, işçi ve benzeri) temel kavramları kararlı bir şekilde ve çekinmeden terk etmek ve siyaset felsefemizi tek ve biricik bir figür olan mülteci figüründen başlayarak yeniden inşa etmek zorunda kalacağız" (Agamben, 2000, s. 15).
}

Bu öneriyi Türkiye’nin güncel bağlamına bir adım daha yaklaştırarak şunu söylemek mümkün; yeni anayasa yapma arifesinde olan Türkiye’nin, “yaklaşmakta olan ortaklık"24 figürü mülteciden çok mülteci annedir.

24 Bu ifade, Agamben’in "Yaklaşmakta Olan Ortaklık" kitabından esinlenilmiştir. 


\section{Sonuç}

Mevcut mülteci krizinin, kısmen cinsiyet temelli ayrımcılık üzerine inşa olmuş Suriye iç hukukundan, kısmen de ulus-devlet paradigmasının çıkmazlarından ötürü, gelecek kuşaklara yansıyacak büyük çapta bir devletsizlik sorununu beraberinde getireceği öngörülmektedir. Bu krizin en mağdurları, kuşkusuz, çocuklarına kimlik çıkartamayan ve onlarla bir başına bırakılan göçmen kadınlardır. Göçmen kadınların yoksulluğu, onların vatandaşlığa ilişkin hak mahrumiyetlerinin doğal sonucu gibi görünmelidir; yoksulluk onlar için vatansız bırakılmış olmanın getirdiği toplumsal bir sorundur. Dolayısıyla göçmen kadının içinde bulunduğu yoksulluk apaçık bir biçimde siyasi krizin öncelediği, tam da bu nedenle çözümünü yine siyaset zemininde bulacağı bir sorun olarak ele alınmalıdır.

Bu makalede göçmen kadının karşı karşıya kaldığı yoksulluk sorunu, siyaset kuramcısı Hannah Arendt'in sunduğu ulus-devlet paradigmasının krizi içerisinden ele alınmıştır. Suriyeli göçmen kadınların yoksulluk ve aslında diğer toplumsal sorunlarının çözümü, yine Arendt'in toplumsal olanı siyasal olana tahvil edebilme kapasitesinde gerçekleşecektir. Bu siyasi kapasite, uluslararası insani yardım kuruluşlarından bağımsız, tek tek devletlerin egemen siyasi otoritesinde aranmalıdır. T.C. Cumhurbaşkanı Başdanışmanı Mehmet Uçum’un kaleme aldığı "'Yurt edinme hakkı' gerçek olabilir mi?" adlı makale, Türkiye egemen siyasi iradesinin mülteci krizini, uluslararası hukuka bırakılmayacak kadar siyasi bir mesele olduğunu kavramış olduğuna işaret eder. Makalede mevcut ulus-devlet sınırlarının, doğal hak olarak tanınan coğrafi hareketlilik hakkını artık kaldıramayacak kadar hantallaştığı ve bu nedenle yurt edinme hakkının kademeli ve koşullu da olsa tanınması gerektiği öne sürülmüştür. Başdanışman Uçum'un belirttiği gibi, olası yerleşme hakkına aynı zamanda istihdam ve kamusal alana katılma hakkı eşlik edecektir. Göçmen kadınların yoksulluk ve diğer toplumsal sorunlarının çözümü, ancak böyle bir hak siyasetiyle olanaklıdır.

\section{Kaynakça}

Agamben, G. (1998). Homo sacer: Sovereign power and bare life, Stanford University Press. Agamben, G. (2000). Means without end: Notes on politics, University of Minesota Press. Arendt, H. (1994). İnsanlık durumu, İletişim Yayınları.

Arendt, H. (2014). Totalitarizmin kaynakları/2: Emperyalizm, İletişim Yayınları.

Barnes, J. (Ed). (1983). Complete Works of Aristotle, Volume 2: The Revised Oxford Translation (Vol 2), Princeton University Press.

Black, I. (2016). Report on Syria conflict finds $11.5 \%$ of population killed or injured. The Guardian. http://www.theguardian.com/world/2016/feb/11/report-on-syria-conflict-finds-115-of-population-killed-or-injured (11 Şubat 2016) 
Brubaker, R. (1994). Citizenship and nationhood in France and Germany, Harvard University Press.

Collins, D. (2016). Refugee women in Lebanon show incredible resilience despite exploitation and abuse. The Huffington Post. http://www.huffingtonpost.com/entry/refugee-women-lebanon-exploitation_us_56c22cd5e4b08ffac1260ee7 (11 Şubat 2016)

Edwards, A. (2015). 'Refugee' or 'migrant' - Which is right? UNHCR News and Stories. http://www.unhcr.org/55df0e556.html (11 Şubat 2016)

Gaynor, T. (2015). 2015 likely to break records for forced displacement study. UNHCR News and Stories. http://www.unhcr.org/5672c2576.html (11 Şubat 2016)

Gündoğdu, A. (2015). Rightlessness in an age of rights: Hannah Arendt and the contemporary struggles of migrants, Oxford University Press.

Heller, A. (1990). Can modernity survive?, University of California Press.

Hobsbawm, E. (1994). Kısa 20. Yüzyıl: 1914-1991 Aşırılıklar Çağı, Everest Yayınları.

Osborne, L., Russell, R. (2015). Refugee crisis creates stateless generation of children in limbo. The Guardian. https://www.theguardian.com/world/2015/dec/27/refugee-crisis-creating-stateless-generation-children-experts-warn (11 Şubat 2016)

Pitkin, H. F. (1998). The attack of the blob: Hannah Arendt's concept of the social, University of Chicago Press.

Reardon, C. (2014). Syrian refugee women fight for survival as they head families alone. UNHCR News and Stories. http://www.unhcr.org/53bb77049.html (11 Şubat 2016)

Uçum, M. (2016). 'Yurt edinme hakki' gerçek olabilir mi? Serbestiyet. http://www.serbestiyet.com/yazarlar/mehmet-ucum/yurt-edinme-hakki-gercek-olabilir-mi-660777 (11 Şubat 2016)

Unal, S. (2015). The Syrian refugee mother transforming women's lives in Turkey. UNHCR News and Stories http://www.unhcr.org/55b9f4689.html (11 Şubat 2016)

UNHR. (1989). Convention on the Rights of the Child. http://www.ohchr.org/EN/ProfessionalInterest/Pages/CRC.aspx (11 Şubat 2016)

Resmi Gazete. (2014). Geçici Koruma Yönetmeliği. http://www.resmigazete.gov.tr/eskiler/2014/10/20141022-15-1.pdf (11 Şubat 2016)

Syrian Center for Policy Research-SCPR. (2016). Confronting Fragmentation. http:// scpr-syria.org/publications/policy-reports/confronting-fragmentation/(11 Şubat 2016)

İç İşleri Bakanlığı. (1964). Türk Vatandaşlı̆̆ı Kanununun Uygulanmasına İlişkin Yönetmelik. http://www.nvi.gov.tr/Files/File/Mevzuat/Yururlukten_Kaldirilanlar/Yonetmelik/ pdf/turk_vatandasligi_kanu_uyg_yonetmelik.pdf (11 Şubat 2016) 